\title{
Meningkatkan Hasil Belajar IPA Materi Perkembangbiakan Tumbuhan dengan Metode out door study pada Siswa Kelas VI SDN Dasan Baru Impres Tahun Pelajaran 2018/2019
}

\author{
Lalu Darwan \\ Guru kelas SDN Dasan Baru Inpres Kecamatan Pringgarata Kabupaen Lombok Tengah
}

\begin{abstract}
Abstrak. Jenis penelitian ini adalah Penelitian Tindakan Kelas dengan subjek penelitian siswa kelas VI SDN Dasan Baru Impres yang berjumlah 15 orang Penelitian ini berlangsung dalam dua siklus. Instrumen yang digunakan adalah lembar tes. Data dianalisis secara deskriptif kualitatif dan kuantitatif. Indikator keberhasilan penelitian ini adalah jika minimal $\geq 80 \%$ siswa telah mencapai KKM yaitu 70 dan nilai rata-rata kelas mengalami peningkatan tiap siklusnya. Berdasarkan hasil belajar siswa yang diperoleh mulai dari siklus I ke siklus II terus menunjukkan peningkatan hasil belajar yang signifikan dari siklus I diperoleh nilai rata - rata sebesar 67,1 kemudian meningkat pada siklus II nilai rata - rata diperoleh sebesar 84,8 terjadi peningkatan sebesar 17,1 poin, kemudian jumlah siswa yang tuntas pada siklus I sebanyak 8 orang dengan persentase sebesar $53 \%$, kemudian meningkat pad siklus II jumlah siswa yang tuntas sebanyak 14 orang dengan persentase sebesar 93\% terjadi peningkatan sebesar 40 poin, dengan demikian maka ketuntasan klasikal yang dipersyaratkan sebesar $\geq 80 \%$ juga sudah tercapai , sehingga penelitian ini di hentikan sampai pada siklus II. Maka dengan denikikan dapat kesimpulan bahwa dengan menggunakan metode out door study dapat meningkatkan hasil belajar IPA materi perkembangiakan tubuhan pada siswa kelas V1 SDN Dasan Baru Impres tahun pelajaran 2018 / 2019 .
\end{abstract}

\section{Kata kunci: Hasil Belajar IPA dan Metode out door study}

\section{PENDAHULUAN}

Pada proses pembelajaran, guru memiliki peranan dan tanggung jawab yang sangat besar dalam pencapain tujuan pembelajaran. Guru dituntut untuk memiliki kemampuan merancang dan menggunakan model pembelajaran yang dapat menumbuhkan cara berpikir siswa agar menjadi lebih kritis, kreatif, dan lebih cepat dalam memahami materi pelajaran. Pada pembelajaran IPA, guru diharapkan dapat meningkatkan hasil belajar siswa. Dengan hasil belajar siswa yang tinggi, guru telah mampu mencapai tujuan pembelajaran.

Upaya meningkatkan hasil belajar siswa merupakan tantangan yang selalu dihadapi oleh setiap orang yang berkecimpung dalam dunia pendidikan. Banyak upaya yang telah dilakukan dan banyak pula keberhasilan yang telah dicapai, meskipun keberhasilan itu belum sepenuhnya memberikan kepuasan bagi masyarakat dan para guru, sehingga sangat menuntut renungan, pemikiran dan kerja keras orang- orang yang berkecimpung di dunia pendidikan untuk memecahkan masalah yang dihadapi. "Guru dikatakan berhasil apabila pembelajaran yang diberikan mampu mengubah perilaku sebagian besar peserta didik kearah penguasaan kompetensi dasar yang lebih baik( Kaswara ;2008;3).

Kemampuan guru dalam menggunakan metode yang sesuai dengan tujuan dan materi pelajaran merupakan kunci keberhasilan dalam pencapaian prestasi belajar siswa. Tuntutan tersebut mutlak dilakukan oleh seorang guru dalam proses pembelajaran khususnya dalam belajar IPA. Hal tersebut juga sejalan dengan tuntutan kurikulum saat ini yang sangat memperhatikan kepentingan metode-metode pembelajaran yang digunakan. Guru dituntut untuk pandai-pandai dalam memilih metode atau model pembelajaran yang tepat, karena "ciri-ciri guru yang baik adalah guru yang bisa menyesuaikan metode mengajar dengan bahan pembelajaran.(Muhibbin 2010;1) 
Berdasarkan hasil ulangan harian yang dilaksanakan di SDN Dasan Baru Impres pada mata pelajaran IPA materi Perkembangbiakan Tumbuhan dari 15 siswa yang tuntas belajar hanya 4 siswa dengan persentase sebesar $27 \%$ dan siswa yang belum tuntas sebanyak 11 siswa dengan persentase sebesar $73 \%$, sedangkan KKM yang ditetapkan di SDN Dasan Baru Impres untuk Mata Pelajaran IPA pada tahun pelajaran 2018 / 2019 adalah 70 dengan ketuntasan klasikal sebesar $\geq 80 \%$.

Ternyata rendahnya hasil belajar siswa dikarenakan tidak menggunakan media pembelajaran sehingga siswa menjadi bosan karena tidak ada yang menjadi jembatan penghubung antara guru dan siswa sehingga tujuan pembelajaran dapat tercapai , dalam Pembelajaran IPA harus melibatkan keaktifan peserta didik secara penuh (Active Learning) dengan merealisasikan pembelajaran yang mampu memberikan kesempatan pada peserta didik untuk melakukan keterampilannya sendiri. Adapun keterampilan tersebut meliputi: kemampuan mencari, menemukan, menyimpulkan, mengkomunikasikan sendiri berbagai pengetahuan, nilai-nilai dan pengalaman yang dibutuhkan.

Pembelajaran IPA yang baik harus mengaitkannya dengan kehidupan sehari-hari siswa. Pembelajaran IPA pada tingkat sekolah dasar sebisa mungkin didasarkan pada pendekatan empirik dengan asumsi bahwa alam raya ini dapat dipelajari, dipahami dan dijelaskan, Misalnya observasi, eksperimen dan analisis rasional. Seperti yang telah dipaparkan oleh Nasution Bahwa: "Pada usia pra-sekolah anak-anak memperoleh stimulus dari benda-benda untuk belajar seperti mainan, perabot rumah, binatang, tanaman dan sebagainya.( Nasution; 2009 ;195).

Kenyataan yang telah dipaparkan di atas merupakan alasan yang membuat peneliti tertarik untuk meneliti dan mencoba menerapkan penggunaan media pembelajaran berupa apotek hidup dimana siswa dapat melihat secara langsung apa yang ingin dipelajari secara langsung sebagai media transformasi konsep yang disampaikan dalam pembelajaran dan memilih judul “ Meningkatkan Hasil Belajar IPA Materi Perkembangbiakan tumbuhan dengan metode Outdoor Study pada Siswa Kelas VI SDN Dasan Baru Impres Tahun Pelajaran 2018 /2019."

\section{Rumusan Masalah}

Dari latar belakang diatas maka masalah yang dikaji dalam penelitian ini dapat dirumuskan sebagai berikut Bagaimanakah Meningkatkan Hasil Belajar IPA Materi Perkembangbiakan tumbuhan dengan metode Outdoor Study pada Siswa Kelas VI SDN Dasan Baru Impres Tahun Pelajaran 2018 /2019."

\section{Tujuan Penelitian}

Berdasarkan rumusan masalah di atas, maka tujuan penelitian ini adalah Untuk Meningkatkan Hasil Belajar IPA Materi Perkembangbiakan tumbuhan dengan metode Outdoor Study pada Siswa Kelas VI SDN Dasan Baru Impres Tahun Pelajaran 2018 /2019."

\section{Manfaat Penelitian}

Adapun manfaat yang dihatapkan dari penelitian ini yaitu :Mendapatkan pengalaman nyata dalam melakukan proses pembelajaran yang menyenangkan. Sehingga hasil belajar siswa meningkat

\section{LANDASAN TEORI DAN KAJIAN PUSTAKA \\ Ilmu Pengetahuan Alam}

Ilmu Pengetahuan Alam (IPA) berhubungan dengan cara mencari tahu tentang alam secara sistematis, sehingga IPA bukan hanya penguasaan kumpulan pengetahuan yang berupa fakta-fakta, konsep-konsep, atau prinsip-prinsip saja tetapi juga merupakan suatu proses penemuan. Kata IPA merupakan terjemahan dari bahasa inggris yaitu "Natural Science" secara singkat sering disebut "science "Sains (Science) diambil dari bahasa latin yang arti harfiahnya adalah pengetahuan. Adapun pengetahuan itu sendiri artinya segala sesuatu 
yang diketahui oleh manusia. Jadi secara singkat IPA adalah pengetahuan rasional dan objektif tentang alam semesta dengan segala isinya. Jadi ilmu pengetahuan alam merupakan ilmu yang pokok bahasannya adalah alam dan segala isinya"( Triyanti; 2010; 100)

Adapun Wahyana dalam Triyanto mengatakan bahwa IPA adalah suatu kumpulan pengetahuan tersusun secara sistematik dan dalam penggunaannya secara umum terbatas pada gejala-gejala alam".(Triyanto; 2010; 136) Sedangkan "Menurut H.W Fowler dalam Triyanto IPA adalah pengetahuan yang sistematis, dirumuskan dan berhubungan dengan gejalagejala kebendaan dan didasarkan atas pengamatan dan dedikasi"( Triyanto; 2010; 136) Dari paparan di atas dapat disimpulkan bahwa IPA adalah suatu kumpulan teori yang sistematis yang pokok bahasannya adalah gejala-gejala alam dan segala isinya.

\section{Hakikat dan Karakteristik IPA di SD}

"Hakikat IPA memiliki empat unsur yang utama yaitu pertama, sikap ingin tahu tentang benda, fenomena alam, mahluk hidup serta hubungan sebab akibat yang menimbulkan masalah baru yang dapat dipecahkan melalui prosedur yang benar. Kedua,proses prosedur pemecahan masalah: Metode ilmiah meliputi penyusunan hipotesis, perencanaan, eksperimen, evaluasi, pengukuran dan penarikan kesimpulan. Ketiga, Produk: berupa fakta, prinsip, teori dan hukum. Keempat, Aplikasi: penerapan metode dan konsep IPA dalam kehidupan sehari-hari. Keempat unsur tersebut merupakan ciri IPA yang utuh serta tidak dapat dipisahkan satu sama lain" ( Triyanti; 2010; 100)

\section{Metode Outdoor.}

\section{Pengertian Metode Mengajar di Luar Kelas (Outdoor).}

Sebagaimana diketahui, tugas utama seorang guru adalah mengajar, mengajar di luar kelas (Outdoor) ialah suatu kegiatan mentransfer Knowledge (ilmu pengetahuan) kepada orang lain. Sedangkan pengertian mengajar di luar kelas secara khusus adalah kegiatan belajar mengajar antara guru dan murid, namun tidak dilakukan di dalam kelas, tetapi dilakukan di luar kelas atau dalam alam terbuka sebagai kegiatan pembelajaran siswa.

"Metode mengajar di luar kelas juga dapat difahami sebagai sebuah pendekatan pembelajaran yang menggunakan suasana di luar kelas sebagai situasi pembelajaran, sebagai media transformasi konsep yang disampaikan dalam pembelajaran. Sebagian orang menyebutnya Outting class, yaitu suatu kegiatan yang melibatkan alam secara langsung untuk dijadikan sebagai sumber belajar.(Adelia Vera; 2012; 17)

Dengan demikian, pembelajaran di luar kelas merupakan suatu kegiatan menyampaikan pelajaran di luar kelas, sehingga kegiatan atau aktivitas belajar mengajar berlangsung di luar kelas atau di alam bebas.

\section{Tujuan Pokok Mengajar di Luar Kelas (Outdoor)}

Alasan menyelenggarakan kegiatan belajar mengajar di luar kelas bukan sekedar karena bosan mengajar di dalam kelas ataupun karena merasa jenuh belajar diruangan tertutup. Akan tetapi, lebih dari itu kegiatan belajar mengajar di luar kelas memiliki tujuan-tujuan pokok yang ingin dicapai sesuai dengan cita-cita pendidik.

"Secara umum, tujuan pendidikan yang ingin dicapai melalui aktivitas belajar di luar ruangan kelas atau di luar lingkungan sekolah ialah sebagai berikut. (a) Mengarahkan peserta untuk mengembangkan bakat dan kreativitas mereka dengan seluas-luasnya di alam terbuka. Selain itu, kegiatan belajar mengajar di luar kelas juga bertujuan untuk memberikan ruang kepada mereka untuk mengembangkan inisiatif personal mereka. Memberi konteks dalam proses pengenalan berkehidupan social dalam tataran praktik (kenyataan di lapangan), (b) Menunjang keterampilan dan ketertarikan peserta didik. Bukan hanya ketertarikan 
terhadap mata pelajaran tertentu yang bisa dikembangkan diluar kelas, melainkan juga ketertarikan terhadap kegiatan di luar kelas, (c) Mengenal berbagai kegiatan di luar kelas yang dapat membuat pembelajaran lebih kreatif.

\section{Tahap-Tahap Pembelajaran di Luar Kelas (Outdoor)}

Ada beberapa pendapat yang menjelaskan tahapan-tahapan pelaksanaan pembelajaran di luar kelas. Menurut Selvi Ayu Utami, langkah-langkah pembelajaran Outdoor yaitu: pra kegiatan, pendahuluan, pengembangan, penerapan, dan penutup. Pra kegiatan yaitu membentuk kelompok heterogen dan merancang aktivitas kelompok, sedangkan pelaksanaan tahap pertama yaitu pendahuluan, kegiatan pendahuluan terdiri dari menyebutkan tujuan pembelajaran, informasi awal materi, menentukan tugas masing-masing kelompok, dan menentukan waktu/membagi waktu. Tahap kedua yaitu pengembangan, kegiatan pengembangan meliputi; siswa secara kelompok melaksanakan tugas yang telah diberikan, guru memotivasi dan memantau kegiatan siswa dalam setiap kelompok, siswa kembali berkumpul setelah waktu habis, siswa bersama guru membahas hasil kerja kelompok dan guru memberikan penguatan. Tahap ketiga yaitu penerapan, kegiatan penerapan merupakan tahap evaluasi bagi siswa, siswa mengerjakan soal-soal secara individu. Tahap keempat penutup, kegiatan penutup meliputi siswa bersama guru menyimpulkan pembelajaran yang baru dipelajari dan guru memberikan tindak lanjut.( Selvi Ayu Utami; 2014; 18)

\section{Hasil Belajar Siswa}

Hasil belajar berasal dari dua kata yaitu "hasil dan "belajar". Hasil merupakan suatu perolehan akibat dilakukannya suatu aktivitas atau proses yang mengakibatkan berubahnya input secara fungsional.( Purwanto;2010; 44). Menurut Djamarah hasil adalah prestasi dari suatu kegiatan yang telah dikerjakan, diciptakan, baik secara individu maupun kelompok.
Arikunto mendefinisikan bahwa hasil belajar adalah hasil akhir setelah mengalami proses belajar, perubahan itu tampak dalam perbuatan yang dapat diamati dan dapat diukur. Sementara Nasution mendefinisikan bahwa hasil belajar adalah suatu perubahan pada diri individu. Perubahan yang dimaksud tidak hanya perubahan pengetahuan, tetapi juga meliputi perubahan kecakapan, sikap, pengertian, dan penghargaan diri pada individu tersebut.( http://duniabaca.com/pengertian belajar dan hasil-hasil belajar.html )

Hasil tidak akan pernah diperoleh selama orang tidak melakukan sesuatu. Untuk menghasilkan sebuah perubahan atau prestasi dibutuhkan perjuangan dan pengorbanan yang sangat besar. Hanya dengan keuletan, sungguh-sungguh, kemampuan tinggi dan rasa optimisme dirilah yang mampu untuk mencapainya.

Hasil belajar adalah kemampuankemampuan yang dimiliki siswa setelah ia menerima pengalaman belajarnya. Hasil belajar merupakan suatu perubahan yang terjadi pada individu yang belajar, bukan hanya perubahan mengenai pengetahuan, tetapi juga untuk membentuk kecakapan, kebiasaan, pengertian, penguasaan, dan penghargaan dalam diri seseorang yang belajar. Hasil belajar merupakan perubahan perilaku yang terjadi setelah mengikuti proses belajar mengajar sesuai dengan tujuan pendidikan.

\section{Perkembangbiakan Tumbuhan.}

Perkembangbiakan tumbuhan dapat melalui biji, tunas, cangkok, dan stek. Sebelum mempelajari cara perkembangbiakan, coba berikan contoh tumbuhan yang berkembang biak dengan biji, tunas, cangkok, dan stek. Perkembangbiakan dengan bagian tubuh tumbuhan atau tanpa melalui perkawinan disebut juga perkembangbiakan cara vegetatif. Perkembangbiakan dengan biji disebut perkembangbiakan dengan cara generatif. Dapatkah kamu membedakan 
perkembangbiakan tumbuhan dengan cara vegetatif atau generatif?

\section{METODE PENELITIAN \\ Setting Penelitian}

Jenis penelitian yang dilakukan oleh peneliti adalah penelitian tindakan kelas (Classroom Action Research). "Penelitian Tindakan Kelas (PTK) adalah suatu pencermatan terhadap kegiatan belajar berupa sebuah tindakan yang sengaja dimunculkan dan terjadi dalam sebuah kelas secara bersama".(Arikunti;2009; 3) Adapun langkah-langkah dalam setiap siklus adalah sebagai berikut: Perencanaan tindakan pelaksanaan tindakan, mengobservasi, mengevaluasi dan refleksi.

\section{Tempat dan waktu penelitian}

Penelitian ini akan dilakasanakan di SDN Dasan Baru Impres yang beralamat di Desa Dasan Baru Kecamatan Pringgarata Kabupaten Lombok tengah, pada semester I Tahun Pelajaran 2018 /2019, Mulai dari bulan juli sampai dengan bulan September 2018 Tahun pelajaran 2018 / 2019.

\section{Subyek Penelitian}

Subyek penelitian ini adalah siswa kelas VI yang berjumlah 15 orang terdiri dari 6 siswa laki - laki dan 9 siswa perempuan ,mereka berasal dari sekitar sekolah dengan kemampuan yang beragam ada yang sangat pandai, ada yang sedang dan ada yang kurang pandai.

\section{Rencana Tindakan}

Penelitian ini direncanakan dalam beberapa siklus.. Masing-masing siklus terdiri dari empat tahapan kegiatan yaitu perencanaan tindakan, pelaksanaan tindakan, observasi dan evaluasi, serta refleksi. (arikunto ;2013; 137) adalah sebagai berikut.

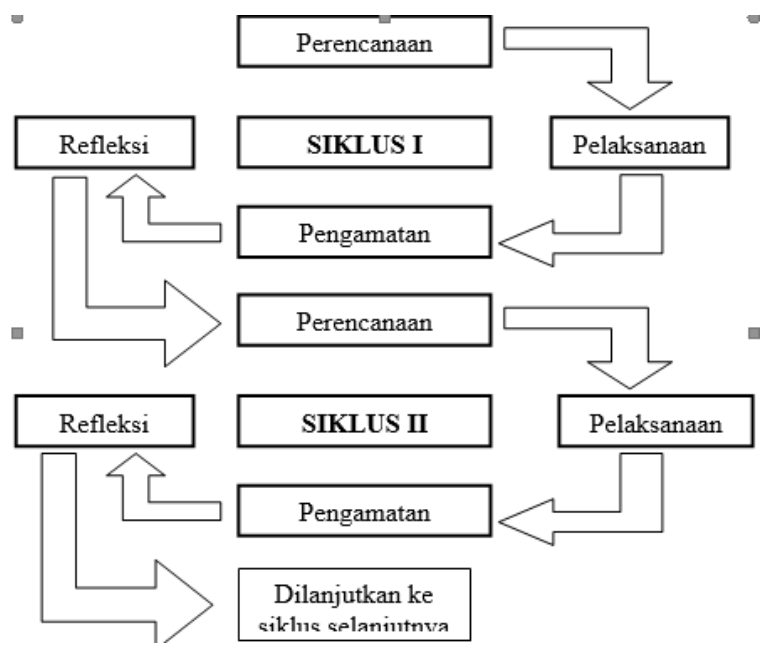

Gambar 1. : Siklus Penelitian Tidakan Jenis Instrument dan Cara Penggunaannya

Jenis instrument yang digunakan untuk mengumpulkan data dalam penelitian ini adalah: Tes Tulis/ Tes Isian (Completion test)"Completion test biasanya kita sebut dengan istilah tes isian, tes menyempurnakan atau tes melengkapi. Completion test terdiri atas kalimat-kalimat yang ada bagianbagiannya yang dihilangkan.( Arikunto; 2009; 175) Bagian yang dihilangkan atau yang harus diisi oleh siswa merupakan pengertian yang kita minta dari murid. Adapun tes isian yang diberikan pada setiap siklus berjumlah 10 soal dengan nilai skor 10 pada masing-masing soal.

\section{Analisis Data}

Analisis data adalah suatu cara yang digunakan dalam pengolahan data yang telah terhimpun dari hasi belajar siswa , sehingga diperoleh informasi-informasi yang guna, dan kemudian dianalisis.

Data Kuantitatif (Data Tes Hasil Belajar Siswa )

Setelah memperoleh data tes hasil belajar, maka data tersebut dianalisis dengan mencari ketuntasan belajar dan daya serap, kemudian dianalisis secara kuantitatif.

1) Ketuntasan Individu

$\mathrm{P}=\frac{X}{S M I} \times 100$

Keterangan:

$\mathrm{P}=$ Persentil

$\mathrm{X}=$ Skor yang dicapai 
SMI = Skor Maksimal Ideal( Wayan Nurkencana;99)

2) Ketuntasan Klasikal

$\mathrm{KK}=\frac{\mathrm{x}}{\mathrm{z}} \times 100 \%$

Keterangan :

KK : Ketuntasan Klasikal

$\mathrm{X} \quad$ : Jumlah siswa yang mencapai nilai $\geq 75$

$\mathrm{z}$ : Jumlah siswa keseluruhan( Wayan Nurkencana;99)

HASIL PENELITIAN DAN
PEMBAHASAN
Hasil Penelitian

Penelitian ini dilaksanakan di

Kelas VI SDN Dasan Baru Impres Kecamatan Pringgarata yang dimulai pada tanggal 24 Juli 2018 sampai dengan September 2018, sesuai dengan surat keterangan telah melaksanakan penelitian yang dikeluarkan oleh SDN Dasan Baru Impres Kecamatan Pringgarata. Adapun penjabaran dari masing-masing siklus adalah sebagai berikut:

\section{Siklus I}

Pelaksanaan pembelajaran pada siklus ini dilaksanakan pada tanggal 24 Juli 2019 yang Dimana peneliti bertindak sebagai pengajar Proses pelaksanaan dilalukan sesuai dengan skenario pembelajaran yang telah disiapkan. Adapun hasil belajar pada siklus I adalah sebagai berikut :

Dari hasil perolehan hasil belajar siswa siklus I diperoleh nilai rata - rata yang sebesar 67,1 jumlah siswa yang tuntas belajar sebanyak 8 siswa dari 15 siswa dengan persentase ketuntasan sebesar $53 \%$ dan siswa yang belum tuntas belajar sebanyak 7 siswa atau persentase $47 \%$ dan ketuntasan klasikal yang dipersyaratkan sebesar $\geq 80 \%$ belum tercapai baru mencapai 53\%, ini dikarenakan siswa masih belum paham dengan petunjuk yang di tuliskan pada LKS dan kurang kontrol oleh guru. Maka dengan demikian penelitian dilanjutkan ke siklus berikutnya.

\section{Siklus II}

Pada siklus II dipersiapkan alokasi waktu 2x 35 menit ditambah dengan 1 jam pelajaran untuk mengadakan evaluasi Jurnal Ilmu Sosial dan Pendidikan hasil belajar, langkah - langkah pembelajaran yang dilakukan pada siklus II sesuai dengan agenda yang sudah tertuang dalam RPP dan pada kegiatan akhir diadakan evaluasi dan , Hasil belajar siswa pada siklus II

Berdasarkan analisa data hasil belajar siswa diperoleh data nilai rata - rata yang diperoleh sebesar 84,8 jumlah siswa yang tuntas belajar sebanyak 14 siswa dengan persentase ketuntasan sebesar $93 \%$ dan siswa yang belum tuntas sebanyak 1 siswa dengan persentase $7 \%$ begitu juga dengan ketuntasan klasikal sudah tercapai sebesar $\geq 80 \%$, ini dikarenakan guru mampu mengatasi kendala yang terjadi pada siklus I Maka dengan demikian penelitian dihentikan sampai siklus II.

\section{Pembahasan}

Penelitian ini dilaksanakan sesuai dengan prosedur penelitian tindakan kelas yang telah ditetapkan yaitu diawali dengan perencanaan, pelaksanaan tindakan, observasi dan refleksi seperti yang telah dijelaskan pada penelitian di atas. Penelitian ini dilaksanakan mulai dari bulan Juli sampai dengan September 2018 di kelas VI SDN Dasan Baru Impres.

Penelitian ini berorientasi pada penerapan metode Out door Study dalam pembelajaran IPA untuk meningkatkan hasil belajar siswa Kelas VI SDN Dasan Baru Impres Kecamatan Pringgarata Tahun pelajaran 2018 /2019. Seperti yang telah dikutip dari Sudjana bahwa "Belajar dengan memanfaatkan alam sekitar dipandang sebagai cara yang lebih bermakna disebabkan para siswa dihadapkan dengan peristiwa dan keadaan yang sebenarnya secara alami, sehingga lebih nyata, lebih faktual dan kebenarannya lebih dapat dipertanggungjawabkan".(Nan Sudjana; 2011; 208)

Hasil belajar siswa siklus I diperoleh nilai rata - rata yang sebesar 67,1 jumlah siswa yang tuntas belajar sebanyak 8 siswa dengan persentase ketuntasan sebesar $53 \%$ dan siswa yang belum tuntas belajar 
sebanyak 7 siswa atau persentase $47 \%$ dan ketuntasan klasikal yang dipersyaratkan sebesar $\geq 80 \%$ belum tercapai baru mencapai $53 \%$, ini dikarenakan siswa masih belum paham dengan petunjuk yang di tuliskan pada LKS dan kurang kontrol oleh guru. Maka dengan demikian penelitian dilanjutkan ke siklus berikutnya.

Dan hasil belajar siswa siklus II diperoleh data nilai rata - rata yang diperoleh sebesar 84,8 jumlah siswa yang tuntas belajar sebanyak 14 siswa dengan persentase ketuntasan sebesar $93 \%$ dan siswa yang belum tuntas sebanyak 1 siswa dengan persentase $7 \%$ begitu juga dengan ketuntasan klasikal sudah tercapai sebesar $\geq 80 \%$, ini dikarenakan guru mampu mengatasi kendala yang terjadi pada siklus I Maka dengan demikian penelitian dihentikan sampai siklus II.

Dari kedua siklus tersebut terlihat peningkatan hasil belajar yang signifikan dari siklus I diperoleh nilai rata - rata sebesar 67,1 kemudian meningkat pada siklus II nilai rata - rata diperoleh sebesar 84,8 terjadi peningkatan sebesar 17,1 poin, kemudian jumlah siswa yang tuntas pada siklus I sebanyak 8 orang dengan persentase sebesar $53 \%$, kemudian meningkat pad siklus II jumlah siswa yang tuntas sebanyak 14 orang dengan persentase sebesar 93\% terjadi peningkatan sebesar 40 poin, dengan demikian maka ketuntasan klasikal yang dipersyaratkan sebesar $\geq 80 \%$ juga sudah tercapai, sehingga penelitian ini di hentikan sampai pada siklus II.

Maka dengan denikikan dapat kesimpulan bahwa dengan menggunakan metode out door study dapat meningkatkan hasil belajar IPA materi perkembangiakan tubuhan pada siswa kelas V1 SDN Dasan Baru Impres tahun pelajaran 2018 / 2019

\section{PENUTUP}

Penelitian ini dilaksanakan sesuai dengan prosedur penelitian tindakan kelas yang telah ditetapkan yaitu diawali dengan perencanaan, pelaksanaan tindakan, observasi dan refleksi seperti yang telah dijelaskan pada penelitian di atas. Penelitian ini dilaksanakan mulai dari bulan Juli Sampai dengan September 2018 .Penelitian ini terdiri dari II siklus dengan 15 siswa sebagai subyek penelitian

Berdasarkan hasil belajar siswa yang diperoleh mulai dari siklus I ke siklus II terus menunjukkan peningkatan hasil belajar yang signifikan dari siklus I diperoleh nilai rata - rata sebesar 67,1 kemudian meningkat pada siklus II nilai rata - rata diperoleh sebesar 84,8 terjadi peningkatan sebesar 17,1 poin, kemudian jumlah siswa yang tuntas pada siklus I sebanyak 8 orang dengan persentase sebesar $53 \%$, kemudian meningkat pad siklus II jumlah siswa yang tuntas sebanyak 14 orang dengan persentase sebesar $93 \%$ terjadi peningkatan sebesar 40 poin, dengan demikian maka ketuntasan klasikal yang dipersyaratkan sebesar $\geq 80 \%$ juga sudah tercapai , sehingga penelitian ini di hentikan sampai pada siklus II.

Maka dengan denikikan dapat kesimpulan bahwa dengan menggunakan metode out door study dapat meningkatkan hasil belajar IPA materi perkembangiakan tubuhan pada siswa kelas V1 SDN Dasan Baru Impres tahun pelajaran 2018 / 2019 .

\section{DAFTAR PUSTAKA}

Arikunto, Suharsimi, Dasar-dasar Evaluasi Pendidikan. Jakarta: Bumi Aksara, 2009.

Arikunto, Suharsimi, dkk. Penelitian Tindakan kelas. Jakarta: Bumi Aksara, 2009

Arikunto, Suharsimi, Dkk. Prosedur Penelitian Suatu Pendekatan Praktik. Jakarta: Rineka Cipta, 2013.

Djamarah, Syaiful Bahri. Dkk. Strategi Belajar Mengajar. Jakarta: Rineka Cipta, 2013.

http://duniabaca.com/Pengertian belajar dan hasil belajar.html/

Kaswara, Deni. Bagaimana Menjadi Guru Kreatif. Bandung: Bumi Aksara, 2008. 
Muhibbin Syah. Psikologi Belajar. Jakarta: Rajawali Pers, 2010.

Mulyati, Arifin. Dkk. Ilmu Pengetahuan Alam dan Lingkungan Untuk KELAS VI SD/MI. Jakarta: PT Setia Purna Invest, 2008.

Nasution. Berbagai Pendekatan Dalam Proses Belajar dan Mengajar. Jakarta: PT Bumi Aksara, 2009.

Purwanto, Evaluasi Hasil Belajar, Yogykarta:Pustaka Pelajar. 2010.

Purwanto, Ngalim. Evaluasi Hasil Belajar. Yogyakarta: Pustaka Pelajar, 2010 .

Sagala, Syaiful. Makna dan Konsep Pembelajaran. Bandung: Alfabeta, 2006.

Slameto. Belajar dan Faktor-faktor yang Mempengaruhinya. Jakarta: Rineka Cipta, 2010.

Sudjana, Nana. Dasar-dasar Proses Belajar Mengajar. Bandung: Sinar Baru Aglensindo. 2011.

Triyanto. Model Pembelajaran Terpadu. Jakarta: PT Bumi Aksara, 2010. 